\title{
Characterization of two different types of resistance genes among producers of fortimicin-group antibiotics
}

\author{
Toshio Ohta, Tohru Dairi and Mamoru Hasegawa* \\ Tokyo Research Laboratories, Kyowa Hakko Kogyo Co., Ltd, 3-6-6 Asahi-machi, Machida-shi, Tokyo 194, Japan
}

(Received 5 May 1992; revised 8 September 1992; accepted 17 November 1992)

\begin{abstract}
Fortimicin-A (FTM-A ; astromicin)-resistance genes ( $f m r$ genes) isolated from six producers of the FTM-group of antibiotics were analysed. These genes could be classified into two types by the resistance profiles to aminoglycoside antibiotics and by their DNA homologies. Three genes, $f m r T$ from the istamycin producer Streptomyces tenjimariensis ATCC 31603, fmrS from the sannamycin producer Streptomyces sannanensis IFO 14239 and $f m r H$ from the sporaricin producer Saccharopolyspora hirsuta ATCC 20501, conferred resistance to FTM-A, kanamycin $(\mathrm{Km})$ and neomycin B $(\mathrm{Nm}-\mathrm{B})$, but not to gentamicin $(\mathrm{Gm})$. The other three genes, fmr $O$ from the FTM-A producer Micromonospora olivasterospora ATCC 21819, $f m r M$ from the antibiotic SF-2052 producer Micromonospora sp. SF-2098 (ATCC 31580) and fmrD from the dactimicin producer Dactylosporangium matsuzakiense ATCC 31570, conferred resistance to FTM-A, Km and Gm, but not to Nm-B. No DNA homology was detected between the two types of the resistance genes in Southern-blot analysis. The present results revealed that, in spite of the similarity of their biosynthesis genes, there are at least two different types of resistance genes among the FTM-group antibiotic producers.
\end{abstract}

\section{Introduction}

It is interesting, from the point of view of the evolution and distribution of antibiotic biosynthetic genes, that antibiotics with similar structures are often produced by taxonomically distant micro-organisms (Malpartida et al., 1987; Leskiw et al., 1988; Schiffman et al., 1988; Weigel et al., 1988; Burnham et al., 1989). Fortimicin (FTM)-group antibiotics with unique pseudodisaccharide structures are produced by six strains of four genera, namely Micromonospora olivasterospora ATCC 21819 (FTM-A) (Nara et al., 1977), Micromonospora sp. SF-2098 ATCC 31580 (SF-2052 compounds) (Ohba et al., 1981), Dactylosporangium matsuzakiense ATCC 31570 (dactimicins) (Inoue et al., 1979), Streptomyces tenjimariensis ATCC 31603 (istamycins) (Okami et al., 1979), Streptomyces sannanensis IFO 14239 (sannamycins) (Watanabe et al., 1979) and Saccharopolyspora hirsuta ATCC 20501 (sporaricins) (Deushi et al., 1979).

*Author for correspondence. Tel. 0427252555 (ext. 261); fax 0427268330 .

Abbreviations: FTM-A, fortimicin A; Km, kanamycin; Gm, gentamicin; Nm-B, neomycin B; Sm, streptomycin; CIAP, calf intestine alkaline phosphatase.
The biosynthetic pathway of FTM-A in M. olivasterospora is believed to consist of more than 14 steps (Odakura et al., 1984), and all members of the FTMgroup antibiotics are thought to be synthesized via similar biosynthetic pathways (Dairi \& Hasegawa, 1989; Hotta et al., 1989). Sequence conservation of the glycyltransferase, one of the key enzymes for the biosynthesis of the FTM-group antibiotics, among the FTM-group antibiotic producers suggested that these biosynthesis genes were derived from a common set of ancestral genes (Ohta et al., 1992).

All the FTM-group antibiotic producers exhibit highlevel resistance to FTM-A. We previously isolated the FTM-A resistance gene $(f m r T)$ from the istamycin producer $S$. tenjimariensis, and showed that sequences homologous to $f m r T$ were present in the sannamycin producer $S$. sannanensis and the sporaricin producer $S a c$. hirsuta (Ohta \& Hasegawa, 1989). These findings seemed to indicate that the resistance genes were also conserved among these antibiotic producers. However, very interestingly, recent preliminary hybridization experiments for an expanded range of strains unexpectedly indicated that this was not the case, suggesting the existence of two or more types of resistance genes. In the present study, we cloned the FTM-A-resistance genes ( $\mathrm{fmr}$ genes) from the other five FTM-group antibiotics producers in order 
to compare them in the same genetic background and screen for sequences similar to $f m r$ genes in other actinomycetes.

\section{Methods}

Bacterial strains and plasmids. S. sannanensis IFO 14239, Sac. hirsuta ATCC 20501, M. olivasterospora ATCC 21819, Micromonospora sp. ATCC 31580 and D. matsuzakiense ATCC 31570 were used as sources of total DNA for the shot gun cloning experiments of $f m r$ genes. $S$. lividans TK23 was used as a cloning host. Plasmids pIJ702 (Katz et al., 1983), pEN101 (Nagano et al., 1988) and pEN101B in which a BglII site of pEN101 was converted to a BamHI site using a synthetic DNA linker (unpublished data) were used as cloning vectors.

Culture conditions and media. All actinomyces were grown at $30^{\circ} \mathrm{C}$ in SK no. 2 medium (Ohta et al., 1992), or maintained on ATCC no. 5 agar medium. Strains harbouring plasmids carrying $f m r$ genes were grown in medium containing $50 \mu \mathrm{g}$ FTM-A hydrochloride $\mathrm{ml}^{-1}$ (Kyowa Hakko Kogyo).

Determination of the antibiotic resistance patterns of the strains. About $10^{9}$ spores were spread on ATCC no. 5 medium containing 0,25 , $50,125,250$ and $500 \mu \mathrm{g} \mathrm{ml}^{-1}$ of the antibiotics to be tested: FTM-A hydrochloride, $\mathrm{Km}$ sulphate (Sigma), Gm sulphate (Sigma), Nm-B sulphate (Sigma) and streptomycin (Sm) sulphate (Sigma). Growth was monitored after incubation at $30^{\circ} \mathrm{C}$ for $3-5 \mathrm{~d}$.

Preparation and manipulation of DNA. Total DNA and plasmid DNA were isolated by the methods described by Chater et al. (1982) and Kieser (1984), respectively. Restriction endonucleases, calf intestine alkaline phosphatase (CIAP) and T4 DNA ligase were purchased from Boehringer Mannheim or Takara Shuzo. They were used under the conditions specified by the suppliers.

Isolation of fmr genes. Total DNA of S. sannanensis IFO 14239 was partially digested with Sau3AI and ligated to pIJ702 cut by BglII. Total
DNA of Sac. hirsuta ATCC 20501 was digested with BamHI and ligated to pEN101B cut by BamHI. Total DNA of M. olivasterospora ATCC 21819 was partially digested with Sau3AI and ligated to pEN101 cut by BglII. Total DNA of Micromonospora sp. SF-2098 ATCC 31580 was partially digested with Sau3AI and ligated to pEN101 cut by BglII. Total DNA of D. matsuzakiense ATCC 31570 was digested with $S a c I$ and ligated to pEN101 cut by $S a c I$. All of these digested plasmid vectors were used after CIAP treatment. Protoplasts of $S$. lividans TK23 were transformed with these ligated DNA preparations and regenerated on R5 medium (Hintermann et al., 1984). Thiopeptin-resistant transformants were obtained by overlaying with soft-agar medium consisting of Nutrient broth (Difco) $0.5 \%(\mathrm{w} / \mathrm{v})$, Bacto agar (Difco) $0.5 \%(\mathrm{w} / \mathrm{v})$ and $20 \mu \mathrm{g}$ thiopeptin $\mathrm{ml}^{-1}$ (Fujisawa Pharmaceutical). These transformants were replica-plated onto ATCC no. 5 medium containing FTM-A $\left(50 \mu \mathrm{g} \mathrm{m}^{-1}\right)$. After incubation at $30{ }^{\circ} \mathrm{C}$ for 3-5 d, FTM-A-resistant transformants were selected.

Construction of a plasmid carrying both fmrT and fmrO. The $1.5 \mathrm{~kb}$ BamHI fragment containing fmrT in pFMRT3 (Ohta \& Hasegawa, 1989) was ligated to an $f m r O$-containing recombinant plasmid, pFMRO2, partially digested with $B c l l$, and $S$. lividans TK23 was transformed with this DNA preparation. After regeneration on R5 medium without selection by antibiotics, the colonies were transferred to ATCC no. 5 medium containing $50 \mu \mathrm{g} \mathrm{Nm}-\mathrm{B} \mathrm{m} \mathrm{m}^{-1}$. They were then transferred to ATCC no. 5 containing $250 \mu \mathrm{g} \mathrm{Gm} \mathrm{ml}^{-1}$, and the transformants resistant to $\mathrm{Nm}$ and $\mathrm{Gm}$ were selected.

Southern-blot hybridization. For the analysis of the cloned $f m r$ genes, each plasmid was digested as follows: pFMRTB1 with BamHI, pFMRS1 with $B c l$, pFMRH1 with BamHI and $E c o$ RI, pFMRO1 with $B c l$ I, pFMRM1 with $B g l \mathrm{II}$, and pFMRD1 with $S a c I$. In the experiment in which the total DNA from various actinomycetes was probed, all total DNA samples were digested with BamHI. To determine the location of $f m r O$ within the gene cluster for FTM-A biosynthesis, a cosmid clone pGLM559 (Dairi et al., 1993) was digested with MluI or XhoI. These preparations were separated by $0.7 \%$ agarose gel electrophoresis in TAE buffer ( $40 \mathrm{~mm}$-Tris/acetate and $2 \mathrm{mm-EDTA}$, $\mathrm{pH} 8.0$ ), and blotted onto Genescreen plus (New England Nuclear

\section{Table 1. Sensitivities to aminoglycoside antibiotics of test strains and S. lividans transformants carrying various fmr genes}

Bacterial growth was monitored after 3-5 d cultivation on ATCC no. 5 medium containing 0 , $25,50,125,250$ and $500 \mu \mathrm{g} \mathrm{m}^{-1}$ of the antibiotics. Numbers represent the minimum concentrations $\left(\mu \mathrm{g} \mathrm{ml}^{-1}\right)$ of the antibiotics which inhibit the growth of the bacteria. s, Sensitive to $25 \mu \mathrm{g}$ of the antibiotic $\mathrm{ml}^{-1}$.

\begin{tabular}{|c|c|c|c|c|c|}
\hline & FTM-A & $\mathrm{Km}$ & Gms & Nm-B & $\mathrm{Sm}$ \\
\hline S. tenjimariensis & $>500$ & $>500$ & s & 250 & $\mathbf{s}$ \\
\hline S. sannanensis & $>500$ & $>500$ & s & 250 & $\mathbf{S}$ \\
\hline Sac. hirsuta & $>500$ & $>500$ & $\mathbf{s}$ & 250 & $\mathrm{~s}$ \\
\hline M. olivasterospora & $>500$ & $>500$ & $>500$ & $\mathbf{s}$ & $\mathrm{s}$ \\
\hline Micromonospora sp. SF-2098 & $>500$ & $>500$ & $>500$ & $\mathrm{~s}$ & $\mathrm{~s}$ \\
\hline D. matsuzakiense & $>500$ & $>500$ & $>500$ & s & $\mathbf{s}$ \\
\hline S. lividans TK23 & s & $\mathbf{s}$ & $\mathbf{s}$ & $\mathbf{s}$ & $\mathbf{S}$ \\
\hline S. lividans (pFMRTB1) & $>500$ & $>500$ & $s$ & 250 & $\mathbf{s}$ \\
\hline S. lividans (pFMRS2) & $>500$ & $>500$ & $\mathrm{~s}$ & 250 & $\mathbf{s}$ \\
\hline S. lividans (pFMRH1) & $>500$ & $>500$ & $\mathbf{s}$ & 250 & $\mathrm{~s}$ \\
\hline S. lividans (pFMRO2) & $>500$ & $>500$ & $>500$ & $\mathrm{~s}$ & $\mathbf{s}$ \\
\hline S. lividans (pFMRM1) & $>500$ & $>500$ & $>500$ & s & $\mathbf{s}$ \\
\hline S. lividans (pFMRD1) & $>500$ & $>500$ & $>500$ & $\mathrm{~s}$ & $\mathbf{s}$ \\
\hline S. lividans (pFMRTO1)* & $>500$ & $>500$ & $>500$ & 250 & $\mathbf{s}$ \\
\hline
\end{tabular}

* pFMRTO1 is a pFMRO2-derived plasmid carrying both $f m r T$ and $f m r O$, but it does not carry $t s r$. 
Research Products) according to the method of Reed \& Mann (1985). The $0.8 \mathrm{~kb}$ SalI fragment within pFMRTB1 (Fig. $1 a$ ) and the $3.2 \mathrm{~kb}$ $P v u I I$ fragment within pFMRO2 (Fig. $1 d$ ) were used as the ' $f m r T$ probe' and the ' $f m r O$ probe', respectively. These DNA fragments were labelled with $\left[\alpha-{ }^{32}\right.$ P]dCTP (Amersham) by nick-translation. Hybridization was carried out at $65^{\circ} \mathrm{C}$ for $16 \mathrm{~h}$ in $6 \times \operatorname{SSC}(1 \times \mathrm{SSC}$ is $0.15 \mathrm{M}$ $\mathrm{NaCl}$ plus $0.015 \mathrm{M}$-sodium citrate, $\mathrm{pH} 7.2$ ), $5 \times$ Denhardt's solution (Maniatis et al., 1982), $100 \mu \mathrm{g}$ sonicated/denatured calf thymus DNA $\mathrm{ml}^{-1}$, with the radioactive DNA probe. The filters were washed twice for $15 \mathrm{~min}$ at room temperature in $150 \mathrm{ml} 0.5 \times \mathrm{SSC}, 0.2 \%(\mathrm{w} / \mathrm{v}) \mathrm{SDS}$, and four times for $30 \mathrm{~min}$ at $65^{\circ} \mathrm{C}$ in $250 \mathrm{ml} 0.3 \times \mathrm{SSC}, 0.2 \%(\mathrm{w} / \mathrm{v})$ SDS. Autoradiograms were made by exposing the filters to Fuji X-ray films (type AIF RX) at $-80^{\circ} \mathrm{C}$ for $1-2 \mathrm{~d}$.

\section{Results}

Resistance profiles of strains to aminoglycoside antibiotics

Table 1 shows sensitivities of the FTM-group antibiotic producers to various aminoglycoside antibiotics. All strains were highly resistant to FTM-A and Km, and were sensitive to Sm. S. tenjimariensis, $S$. sannanensis and Sac. hirsuta were resistant to $\mathrm{Nm}-\mathrm{B}$, but sensitive to $\mathrm{Gm}$. In contrast, $M$. olivasterospora, Micromonospora sp. SF-2098 and D. matsuzakiense were resistant to $\mathrm{Gm}$, but sensitive to $\mathrm{Nm}-\mathrm{B}$. The $f m r T$ gene isolated from $S$. tenjimariensis was considered to be a resistance gene for self-defence because of the structural similarity of FTMA and istamycin A, its own product (Ohta \& Hasegawa, 1989). The gene conferred resistance to Nm-B; however, M. olivasterospora, Micromonospora sp. SF-2098 and D. matsuzakiense were sensitive to this antibiotic. These results indicated the presence of two or more different types of resistance genes in these producers. As $S$. lividans TK23 was sensitive to these antibiotics (Table 1), it was used as the host to clone the resistance genes.

\section{Isolation of fmr genes}

Isolation of $f m r T$ from the istamycin producer $S$. tenjimariensis was previously described (Ohta \& Hasegawa, 1989). The physical map of the cloned DNA in pFMRTB1 is shown in Fig. 1 (a). Although Skeggs et al. (1987) cloned an aminoglycoside-resistance gene ( kamA ; kanamycin-apramycin resistance methyltransferase) from the same strain of $S$. tenjimariensis, its physical map was quite different from our clone (Skeggs et al., 1985, 1987). In the present study, $f m r$ genes were cloned into $S$. lividans TK23 from the other five strains. Plasmids pIJ702, pEN101 and pEN101B were used as vectors. Plasmid pEN101 is a multi-copy plasmid which is similar in length, copy number and stability to those of pIJ702 (unpublished data); pEN101B is a pEN101 derivative.

From the sannamycin producer $S$. sannanensis IFO 14239, four FTM-A-resistant transformants were ob- tained in the shotgun cloning experiment. These plasmids, pFMRS1, pFMRS1, pFMRS2, pFMRS3 and pFMRS4, contained $1.5,2.3,1.6$ and $1.4 \mathrm{~kb}$ inserts, respectively. The resistance determinant, $f m r S$, should be located within the common $1.3 \mathrm{~kb}$ region in these cloned DNA fragments. Fig. 1(b) shows the physical map of the insert in pFMRS2 and the presumed location of $f m r S$. From the sporaricin producer Sac. hirsuta ATCC 20501, one resistant transformant, harbouring $\mathrm{pFMRH1}$, was obtained. pFMRH1 contained a $5.9 \mathrm{~kb}$ Bam $\mathrm{HI}$ fragment (Fig. 1c). During the preparation of this report, the isolation of kamC (see above for designation of kam) of

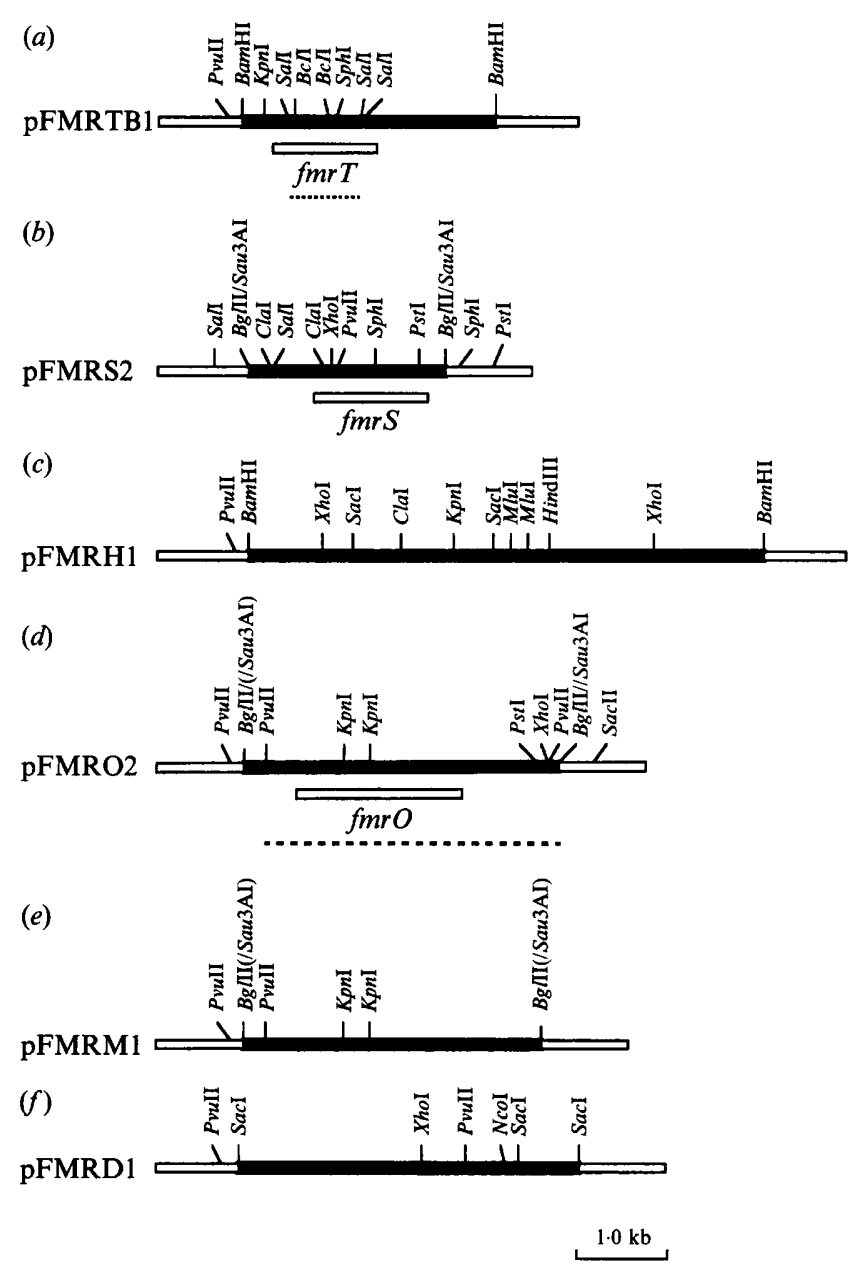

Fig. 1. Physical maps of the cloned DNA fragments containing $f m r$ genes. The restriction maps of the cloned fragments of (a) pFMRTB1 from $S$. tenjimariensis (Ohta \& Hasegawa, 1989), (b) pFMRS2 from $S$. sannanensis, (c) pFMRH1 from Sac. hirsuta (ATCC 20501), (d) pFMRO2 from $M$. olivasterospora, (e) pFMRM1 from Micromonospora sp. SF-2098, and $(f)$ pFMRD1 from $D$. matsuzakiense are shown. The black regions represent the cloned fragments. The location of $f m r T, f m r S$ and $f m r O$ are indicated as open bars under the physical maps. Dotted lines represent the $0.8 \mathrm{~kb} S a l \mathrm{I}$ fragment of the $f m r T$ probe $(a)$ and the $3.2 \mathrm{~kb} P v u I I$ fragment of the $f m r O$ probe $(d)$ used in Southern-blot hybridization analysis. 
another sporaricin producer, Sac. hirsuta CL102, was reported by Holmes et al. (1991). However, the physical map of our clone was quite different from their kamCcontaining DNA fragment; the taxonomic relationship of the two strains is unclear. As the structures of these two resistance genes were different and as the resistance mechanism of our gene has not been clarified, our resistance gene obtained from Sac. hirsuta ATCC 20501 was designated $f m r H$. From the FTM-A producer $M$. olivasterospora, three resistant transformants were obtained. The plasmids, pFMRO1, pFMRO2 and pFMRO3, carried $2 \cdot 6,3.6$ and $3.0 \mathrm{~kb}$ inserts, respectively. The resistance determinant, $f m r O$, should be located within the common $1.9 \mathrm{~kb}$ region in the cloned DNA fragments of these three plasmids. Fig. $1(d)$ shows the physical map of the insert in pFMRO2 and the presumed location of $f m r O$. From the antibiotic SF-2052 producer Micromonospora sp. strain SF-2098, one resistant transformant, harbouring, pFMRM1, was obtained. pFMRM1 contained a $3.4 \mathrm{~kb}$ insert (Fig. 1e). The resistance determinant was designated $f m r M$. From the dactimicin producer $D$. matsuzakiense, one resistant transformant, harbouring pFMRD1 was obtained. Although the shotgun cloning was performed by $S a c I$ digestion, pFMRD1 contained two sacI fragments, of 3.1 and $0.7 \mathrm{~kb}$ (Fig. $1 f$ ).

Similarity was observed between the physical maps of fmrO and fmrM, cloned from two Micromonospora strains; however, no structural similarities were observed among the other genes.

\section{Resistance profiles of fmr genes}

Resistance profiles of $S$. lividans TK23 transformants harbouring each $f m r$ gene were examined. Exact comparison of the resistance levels conferred by resistance genes present in taxonomically different micro-organisms is difficult because of the difference in their optimum growth conditions and the difficulty of controlling their growth rates. We therefore used the homogeneous background of the host $S$. lividans carrying the $f m r$ genes to compare the characteristics of these resistance genes. The results summarized in Table 1 clearly indicate that the resistance patterns of these transformants are similar to those of the corresponding producer strains. These results also show that $f m r$ genes could undoubtedly be classified into two groups with respect to their resistance profiles, namely the Nm-resistant group (designated ' $f m r T$-type', consisting of $f m r T, f m r S$ and $f m r H$ ) and the $\mathrm{Gm}$-resistant group (designated ' $\mathrm{m} m \mathrm{O} O$-type', consisting of $f m r O$, fmrM and $f m r D$ ). The resistance pattern of the $f m r T$-type was similar to the $\mathrm{kam}$ genes isolated from $S$. tenjimariensis (kamA) (Skeggs et al., 1985), a nebramycin producer S. tenebrarius NCIB 11028 (kamB) (Skeggs et $a l ., 1987)$ and a sporaricin producer Sac. hirsuta CL102 (kamC) (Holmes et al., 1991), in spite of the discrepancy (a)

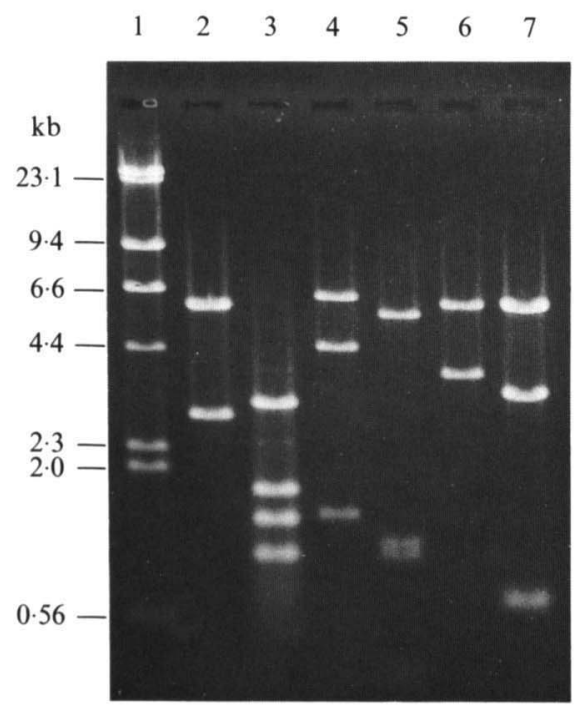

(b)

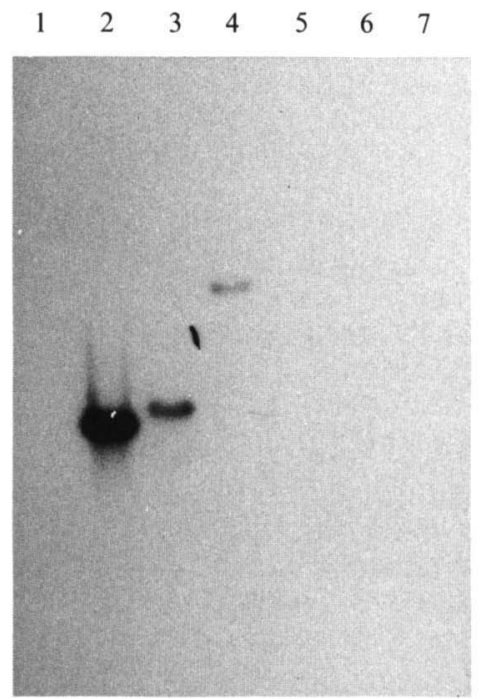

(c)

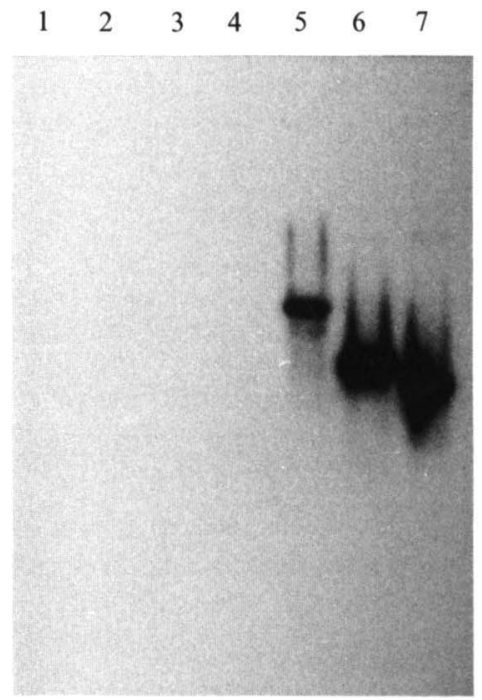

Fig. 2. DNA homologies among the cloned $f m r$ genes. Ethidium bromide-stained gel $(a)$ and the results of Southern-blot hybridization analysis using the $f m r T$ probe $(b)$ and the $f m r O$ probe $(c)$ are shown. The $0.8 \mathrm{~kb} S a l l$ fragment in pFMRTB1 (Fig. $1 a)$ and the $3.2 \mathrm{~kb}$ $P v u I$ fragment in pFMRO2 (Fig. $1 d$ ) as the $f m r T$ and $f m r O$ probes, respectively. Lanes: 1 , size markers ( $\lambda$ phage DNA digested with HindIII); 2, pFMRTB1 digested with $B a m H I$ ( $f m r T$ is contained in the $2.8 \mathrm{~kb}$ fragment); 3, pFMRS1 digested with $B c I I$ ( $f m r S$ is contained in the $3.0 \mathrm{~kb}$ fragment); 4, pFMRHl digested with BamHI and EcoRI (fmrH is contained in the 5.9 kb fragment); 5 , pFMRO1 digested with $B c l$ I $(f m r O$ is contained in the $5.3 \mathrm{~kb}$ fragment); 6, pFMRM1 digested with $B g I I \mathrm{I}(f m r M$ is contained in the $3.4 \mathrm{~kb}$ fragment); 7 , pFMRD1 digested with $S a c \mathrm{I}(\mathrm{fmrD}$ is contained in the $3.2 \mathrm{~kb}$ fragment). 
of the physical maps between $\operatorname{kam} A$ and our $\operatorname{fmr} T$, and between $\operatorname{kamC}$ and our $f m r H$. On the other hand, the resistance pattern of the $f m r O$-type was similar to $\mathrm{Km}$ $\mathrm{Gm}$, resistance genes isolated from the $\mathrm{Km}$ producer Streptomyces kanamyceticus ISP 5500 (Nakano et al., 1984), S. tenebrarius NCIB 11028 ( $k g m B)$ (Skeggs et al., 1987), and the Gm producer M.purpurea ( $\mathrm{grm}$ ) (Kelemen et al., 1991).

An $8.7 \mathrm{~kb}$ plasmid, pFMRTO1, which carried both $f m r T$ and $f m r O$, was constructed by introducing $f m r T$ into pFMRO2, although the plasmid lost a portion of pFMRO2 including $t s r$ during the construction. An $S$. lividans TK23 transformant harbouring pFMRTO1 was resistant to both Nm-B and Gm (Table 1), indicating that these resistance mechanisms worked independently and simultaneously in S. lividans.

\section{DNA homologies of the cloned fmr genes}

Southern-blot hybridization analysis was performed to examine the DNA homologies among the $f m r$ genes. The $0.8 \mathrm{~kb} \mathrm{Sall}$ fragment in pFMRTB1 $(f m r T$; Fig. $1 a)$ and the $3.2 \mathrm{~kb} P v u$ II fragment in pFMRO2 (fmrO; Fig. $1 d$ ) were used as the hybridization probes. The plasmids carrying the $f m r$ genes described above were digested with appropriate restriction enzymes in order to distinguish the cloned DNA fragments from the vector sequences. When the $f m r T$ probe was employed, significant homologies were found in $f m r S$ and $f m r H$, but not in $f m r O, f m r M$ and $f m r D$ (Fig. $2 b$ ). The opposite result was obtained when the $f m r O$ probe was employed (Fig. 2c).

\section{Distribution of DNA fragments homologous to fmrT and $\mathrm{fmrO}$}

Southern hybridization analyses of the total DNA from various actinomycetes were performed to examine the distribution of DNA fragments homologous to $f m r T$ and $f m r O$. When the $f m r T$ probe was employed, a positive signal of $2.8 \mathrm{~kb}$ was detected in $S$. tenjimariensis, which agreed with the cloned fragment by BamHI digestion (Fig. 3, lane 2; Fig. 1a). Positive signals were clearly detected in S. sannanensis and Sac. hirsuta ATCC 20501 as expected, with sizes of 7.0 and $5.9 \mathrm{~kb}$, respectively (Fig. 3, lanes 3 and 11). The size of the signal detected in the sporaricin producer Sac. hirsuta ATCC 20501 agreed with the structure of the cloned fragment by BamHI digestion (Fig. 1c); however, it differed in size from the $2.6 \mathrm{~kb} \mathrm{BamHI}$ fragment containing $\operatorname{kamC}$ in another sporaricin producer, Sac. hirsuta CL102 (Holmes et al., 1991). Sac. hirsuta ATCC 27875 also gave a signal of $2.4 \mathrm{~kb}$ (Fig. 3, lane 13). This strain has not been reported

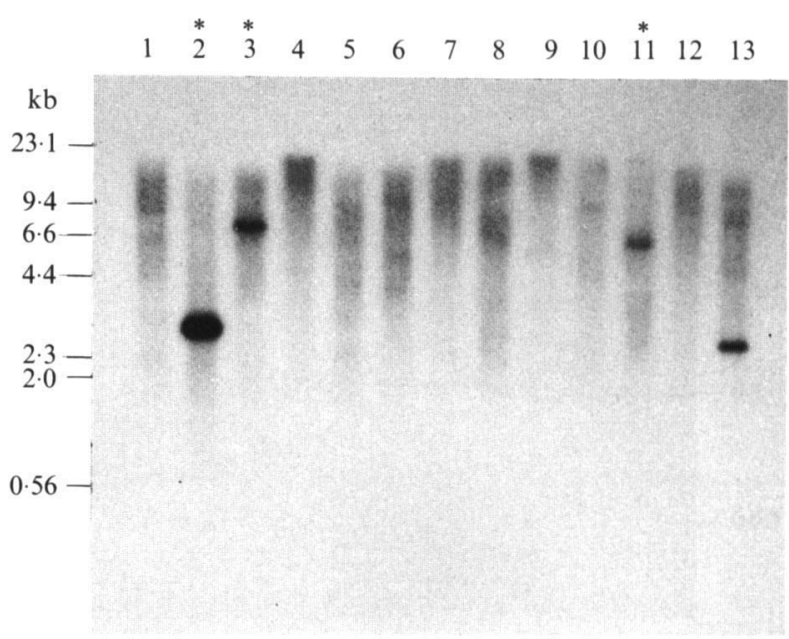

Fig. 3. Distribution of DNA homologous to $f m r T$. The result of Southern-blot hybridization analysis using the $0.8 \mathrm{~kb} \mathrm{Sall}$ fragment in pFMRTB1 (Fig. $1 a$ ) as a probe is shown. Total DNA preparations were digested with BamHI and separated by $0.7 \%$ agarose gel electrophoresis in TAE buffer. Lanes: 1, Streptomyces lividans TK23; 2, Streptomyces tenjimariensis ATCC 31603 (istamycin producer); 3, Streptomyces sannanensis IFO 14239 (sannamycin); 4, Streptomyces fradiae ATCC 10745 (Nm-B); 5, Streptomyces griseus subsp. griseus (Sm); 6, Streptomyces kasugaensis ATCC 15715 (kasugamycin); 7, Streptomyces hygroscopicus subsp. hygroscopicus ATCC 27438 (hygromycin); 8, Streptomyces kanamyceticus ATCC 12853 (Km); 9, Streptomyces ribosidificus ATCC 21294 (ribostamycin); 10, Streptomyces tenebrarius ATCC 17920 (nebramycin); 11, Saccharopolyspora hirsuta ATCC 20501 (sporaricin); 12, Saccharopolyspora hirsuta (MK220) (XK-220, a macrolide antibiotic, unpublished data); 13, Saccharopolyspora hirsuta ATCC 27875. DNA preparations from the strains in Fig. 4 (lanes 1-13) were also probed, but gave no hybridization signals with $f m r T$ (not shown). Positions of the fragments of $\lambda$ phage DNA digested with $H$ indIII are indicated on the left. Asterisks above the lane numbers indicate the producers of the FTM-group antibiotics.

to produce FTM-group antibiotics; however, it showed a similar resistance profile to those of $f m r T$-type resistance genes - resistant to FTM-A, Km and Nm-B, but sensitive to $\mathrm{Gm}$ and $\mathrm{Sm}$. These results suggest that Sac. hirsuta ATCC 27875 has an fmrT-type resistance gene. On the other hand, no signal was detected in $M$. olivasterospora, Micromonospora sp. SF-2098, D. matsuzakiense and other actinomycetes including producers of the other aminoglycoside antibiotics (see legend to Fig. $3)$.

When the $f m r O$ probe was employed, positive signals of approximately 15,15 and $25 \mathrm{~kb}$ were detected in $M$. olivasterospora, Micromonospora sp. SF2098 and D. matsuzakiense, respectively (Fig. 4, lanes 1, 2 and 11). No positive signal was detected in $S$. tenjimariensis, $S$. sannanensis and sporaricin-producing Sac. hirsuta (not shown). Hybridization signals were also commonly detected in Micromonospora strains which produced the other aminoglycoside antibiotics: $6.1 \mathrm{~kb}$ signals in $M$. purpurea ATCC 15835 and three M. echinospora strains, 


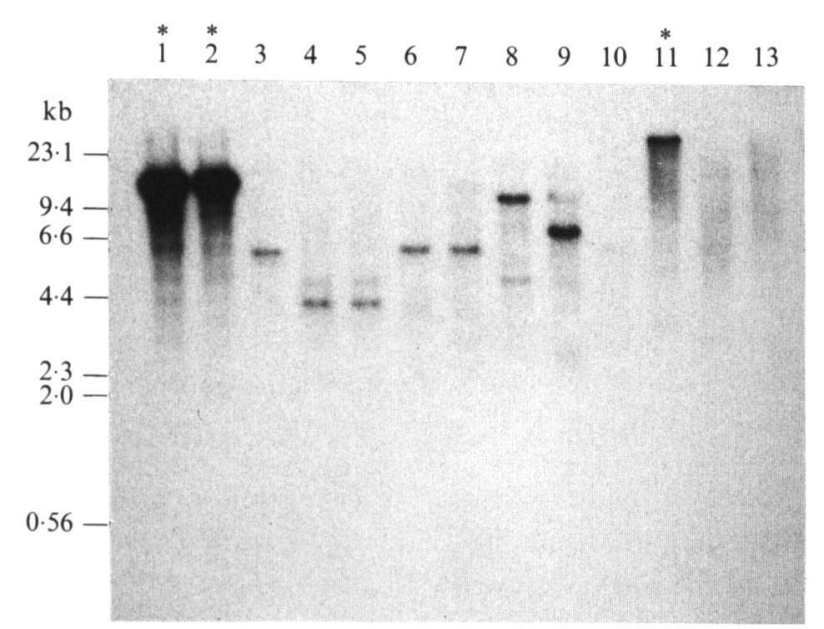

Fig. 4. Distribution of DNA homologous to $f m r O$. The result of Southern-blot hybridization analysis using the $3.2 \mathrm{~kb} P v u I I$ fragment in pFMRO2 (Fig. 1d) as a probe is shown. Lanes: 1, Micromonospora olivasterospora ATCC 21819 (FTM-A); 2, Micromonospora sp. SF2098 ATCC 31580 (SF-2052); 3, Micromonospora purpurea ATCC 15835 (identical to strain DSM 43036; Gms); 4, Micromonospora sagamiensis subsp. nonreducans ATCC 21803 (sagamicins and GmA1); 5, Micromonospora sagamiensis ATCC 21826 (sagamicins and Gm-A1); 6, Micromonospora echinospora subsp. echinospora ATCC 15837 (Gms); 7, Micromonospora echinospora subsp. pallida ATCC 15838 (Gms); 8, Micromonospora inyonensis ATCC 27600 (sisomicins); 9, Micromonospora zionensis IFO 14116 (sisomicins); 10, Micromonospora echinospora subsp. ferruginea ATCC 15836 (Gms); 11, Dactylosporangium matsuzakiense ATCC 31570 (dactimicin); 12, Dactylosporangium aurantiacum ATCC 23491; 13, Dactylosporangium variesporam (capreomycin). DNA preparations from the strains in Fig. 3 (lanes 1-13) were also probed, but gave no hybridization signals with fmrO (not shown). Other details as for Fig. 3 .

ATCC 15837, ATCC 15838 and ATCC 15836 (Gm producers; lanes $3,6,7$ and 10$), 4 \cdot 1 \mathrm{~kb}$ in two $M$. sagamiensis strains, ATCC 21803 and ATCC 21826 (sagamicins and Gm-A1; lanes 4 and 5), an approximately $13 \mathrm{~kb}$ signal and a weak $4.7 \mathrm{~kb}$ signal in $M$. inyonensis ATCC 27600 (sisomicins; lane 8), and a $7 \cdot 3 \mathrm{~kb}$ signal and a weak $13 \mathrm{~kb}$ signal in $M$. zionensis IFO 14116 (sisomicins; lane 9). All these strains were highly resistant to FTM-A (more than $500 \mu \mathrm{g} \mathrm{ml}^{-1}$ ); however, they are not known to produce any FTM-group antibiotics.

\section{Location of fmrO in the gene cluster of FTM-A biosynthesis}

The genes for FTM-A biosynthesis are clustered within an approximately $25 \mathrm{~kb}$ region (Dairi et al., 1993). The $f m r O$ probe hybridized to the $6.4 \mathrm{~kb} \mathrm{MluI}$ and the $6.0 \mathrm{~kb}$ XhoI fragments of pGLM559 carrying the FTM-A biosynthesis gene cluster (Dairi et al., 1993). This indicated that $f m r O$ is adjacent to one end of the gene cluster for FTM-A biosynthesis in the $M$. olivasterospora genome. The size of the signal detected in the Southern analysis of the total DNA (Fig. 4, lane 1) is also consistent with the structure of the gene cluster.

\section{Discussion}

Self-defence against their own products is essential for the growth of antibiotic producers (Hotta et al., 1983). Antibiotic biosynthesis genes are generally clustered in limited regions in the genome, and the genes conferring resistance to the organism's own products are usually located in or near the gene clusters (Rhodes et al., 1984; Ohnuki et al., 1985; Chater \& Bruton, 1985; Malpartida \& Hopwood, 1986; Murakami et al., 1986; Stanzak et al., 1986; Fishman et al., 1987). These facts seem to suggest a tight genetic linkage between antibiotic biosynthesis genes and the resistance genes during the evolution and the horizontal distribution of antibiotic biosynthesis systems.

The FTM-group antibiotics, which are produced by six actinomycetes of four genera, are believed to be synthesized via similar biosynthetic pathways (Dairi \& Hasegawa, 1989; Hotta et al., 1989), and at least parts of these antibiotic biosynthetic genes are conserved among these producers (Ohta et al., 1992). We had previously postulated that the resistance genes for self-defence would also be conserved, like the biosynthesis genes (Ohta \& Hasegawa, 1989). However, the present study showed that the resistance genes of these strains could be clearly classified into two different families with respect to their resistance profiles and DNA homologies. The results suggest that the differences in the resistance patterns are caused by differences in the nucleotide sequences and hence differences in the enzyme structures. Thus there may exist at least two functionally different families of resistance genes among the FTM-group antibiotic producers.

Importantly, $f m r O$ was found to be located adjacent to the gene cluster for FTM-A biosynthesis. It is very curious that the $f m r O$-type resistance genes could not be found in S. tenjimariensis, S. sannanensis and sporaricinproducing Sac. hirsuta, which carry the homologous glycyltransferase gene that is located in this gene cluster.This fact suggests that the biosynthetic genes and the resistance genes have evolved separately in these producers. It can be considered that the genes for antibiotic biosynthesis and resistance are horizontally distributed by genetic transfer, such as conjugation or transduction via phages, in addition to the vertical succession accompanied by bacterial evolution. It is possible that part of the gene cluster for the biosynthesis of FTM-group antibiotics has been transferred inde- 
pendently of its corresponding resistance gene to one of the FTM-group antibiotic producers which had another class of resistance genes. Our results suggest a looser genetic linkage between the antibiotic biosynthesis genes and the self-defence genes during their presumed dissemination among the FTM-group antibiotic producers.

The resistance pattern conferred by the fmrO-type resistance genes was similar to those conferred by the $\mathrm{Km}-\mathrm{Gm}$ resistance gene conferring the ribosome modification isolated from S. kanamyceticus ISP 5500 (Nakano et al., 1984) and by the kanamycin-gentamicin resistance methyltransferase gene $(\mathrm{kgmB})$ of $S$. tenebrarius NCIB 11028 (Skeggs et al., 1987). However, no hybridization signals were detected in these strains using the $f m r O$ probe under the conditions employed in this study. This suggests that the resistance determinant found in $S$. kanamyceticus and $S$. tenebrarius is different from the $f m r O$-type resistance genes, or that the similarity in nucleotide sequences is too small to be detected by this hybridization experiment. The $f m r O$-type resistance genes of Micromonospora and Dactylosporangium are more similar to each other than to those of the Streptomyces strains. This seems to be consistent with the taxonomic distances between the genera Micromonospora, Dactylosporangium and Streptomyces. Recent comparisons of 16S rRNA sequences showed that the former two genera are very closely related, and are distant from Streptomyces and Saccharopolyspora (Stackebrandt \& Charfreitag, 1990).

Positive signals hybridizing to the $f m r O$ probe were commonly detected in Micromonospora strains which produced other aminoglycoside antibiotics, i.e. gentamicins, sagamicins or sisomicins. The signals detected in Micromonospora strains should be resistance genes similar to $f m r O$ considering the high resistance of these strains to FTM-A. The resistance genes with resistance patterns similar to $f m r O$ isolated from $S$. kanamyceticus (Nakano et al., 1984), S. tenebrarius (kgmB) (Skeggs et al., 1987) and M. purpurea (grm) (Kelemen et al., 1991) confer ribosome modification. Ribosomal resistance is a widespread mechanism among aminoglycoside-producing Micromonospora strains (Matkovic et al., 1984). No FTM-A-inactivation activity was detected in $M$. olivasterospora (data not shown). Thus, one can suppose that the $f m r O$-type resistance genes confer such a ribosome modification. It was reported that grm of $M$. purpurea encoded a specific methyltransferase of $16 \mathrm{~S}$ ribosomal RNA (Kelemen et al., 1991). However, the size of the band that hybridized to the $f m r O$ probe in $M$. purpurea ATCC 15835 (identical to strain DSM 43036 used by Piendl et al., 1984) (6.1 kb BamHI fragment; Fig. 4, lane 3 ) was not the same as that which hybridized to the $\mathrm{grm}$ probe in their strain ( $1.9 \mathrm{~kb}$ Bam HI fragment).

It has been shown that the self-defence mechanism of
S. tenjimariensis is ribosomal resistance (Yamamoto et al., 1981, 1986; Piendl et al., 1984; Skeggs et al., 1985), and that its kamA encodes a specific methyltransferase of 16S ribosomal RNA (Beauclerk \& Cundliffe, 1987). The kamA of $S$. tenjimariensis, kamB of $S$. tenebrarius NCIB 11028 and kamC of another sporaricin-producing Sac. hirsuta strain, CL102, have been reported to have DNA similarity (Skeggs et al., 1987; Cundliffe, 1989; Holmes et al., 1991). The fmrT-type resistance genes obtained in this study gave a similar resistance profile to that of the kam type resistance genes. However, the physical map of $f m r T$ disagreed with that of $\operatorname{kamA}$ cloned from the same strain of $S$. tenjimariensis (Skeggs et al., 1987), and no signal hybridizing to the $f m r T$ probe was detected in S. tenebrarius ATCC 17920 under the conditions used in this study. fmrT seems to be the only gene which confers resistance to FTM-A, Km and NmB in our strain. At this stage we cannot explain why $f m r T$ does not appear to be related to kam. Further comparative studies, including sequence analysis, between the $f m r T$ and $k a m$ genes are needed.

Although the two Micromonospora strains which produce the FTM-group antibiotics were independently isolated by different research groups (Nara et al., 1977; Ohba et al., 1981), the patterns of hybridization signals obtained with the $f m r O$ probe agreed well. Such agreement was also observed using the sannamycin Bglycyltransferase gene as a probe (Ohta et al., 1992). These observations suggest that the biosynthetic gene clusters for FTM-A and SF-2052 compounds are well conserved. Similarities in the hybridization signals to the $f m r O$ probe were observed among the producers of the Gm-group antibiotics, $M$. purpurea ATCC 15835, $M$. echinospora subsp. echinospora ATCC 15837, M. echinospora subsp. pallida ATCC 15838 and M. echinospora subsp. ferruginea ATCC 15836, and between $M$. sagamiensis subsp. nonreducans ATCC 21803 and $M$. sagamiensis ATCC 21826. The difference between the former and the latter groups is only in the level and composition of their Gm-group antibiotics. The properties of these antibiotics seem to be correlated with the degree of conservation of the gene organizations around the resistance genes, probably including the biosynthetic genes for these antibiotics.

We are grateful to Dr I. Kawamoto for his critical discussion on the taxonomic field in this study. We also thank Ms K. Fujiwara and Ms K. Naito for their excellent technical assistance.

\section{References}

Beauclerk, A. A. D. \& Cundliffe, E. (1987). Sites of action of two ribosomal RNA methylases responsible for resistance to aminoglycosides. Journal of Molecular Biology 193, 661-671.

Burnham, M. K. R., EARl, A. J., Bull, J. H., SMith, D. J. \& Turner, 
G. (1989). DNA encoding ACV synthetase. European Patent Applications 88311655.0.

Chater, K. F. \& BrUton, C. J. (1985). Resistance, regulatory and production genes for the antibiotic methylenomycin are clustered. EMBO Journal 4, 1893-1892.

Chater, K. F., Hopwood, D. A., Kieser, T. \& Thompson, C. J. (1982). Gene cloning in Streptomyces. Current Topics in Microbiology and Immunology 96, 69-95.

CUNDLIFFE, E. (1989). How antibiotic-producing organisms avoid suicide. Annual Review of Microbiology 43, 207-233.

DaIRI, T. \& Hasegawa, M. (1989). Common biosynthetic feature of fortimicin-group antibiotics. Journal of Antibiotics 42, 934-943.

Dairi, T., OHTA, T. \& HASEgaWA, M. (1993). Organization and nature of fortimicin A (astromicin) biosynthetic genes studied by a cosmid library of Micromonospora olivasterospora. Molecular and General Genetics (in the Press).

Deushi, T., Iwasaki, A., KamiYa, K., Kunieda, T., Mizoguchi, T., NaKayama, M., ITOH, H., Mori, T. \& Oda, T. (1979). A new broadspectrum aminoglycoside antibiotic complex, sporaricin. I. Fermentation, isolation and characterization. Journal of Antibiotics 32, 173-179.

Fishman, S. E., Cox, K., Larson, J. L., Reynolds, P. A., Seno, E. T., Yeh, W. K., Van Frank, R. \& Hershberger, C. L. (1987). Cloning genes for the biosynthesis of a macrolide antibiotic. Proceedings of the National Academy of Sciences of the United States of America 84, 8248-8252.

Hintermann, G., Crameri, R., Vögtli, M. \& Hütter, R. (1984). Streptomycin-sensitivity in Streptomyces glauscesens is due to deletions comprising the structural gene coding for a specific phosphotransferase. Molecular and General Genetics 196, 513-520.

Holmes, D. J., Drocourt, D., Tiraby, G. \& Cundliffe, E. (1991). Cloning of an aminoglycoside-resistance-encoding gene, $\mathrm{kamC}$, from Saccharopolyspora hirsuta: comparison with kamB from Streptomyces tenebrarius. Gene 102, 19-26.

HotTa, K., Takahashi, A., OKami, Y. \& Umezawa, H. (1983). Relationship between antibiotic resistance and antibiotic productivity in actinomycetes which produce aminoglycoside antibiotics. Journal of Antibiotics 36, 1789-1791.

HotTa, K., Morioka, M. \& OKamI, Y. (1989). Biosynthetic similarity between Streptomyces tenjimariensis and Micromonospora olivasterospora which produce fortimicin-group antibiotics. Journal of Antibiotics 42, 745-751.

Inoue, S., Ohba, K., Shomura, T., Kojma, M., Tsuruoka, T., Yoshida, J., Kato, N., Ito, M., Amano, S., Omoto, S., Ezaki, N., ITo, T. \& NiIDA, T. (1979). A novel aminoglycoside antibiotic, substance SF-2052. Journal of Antibiotics 32, 1354-1356.

Katz, E., Thompson, C. J. \& Hopwood, D. A. (1983). Cloning and expression of the tyrosinase gene from Streptomyces antibiotics in Streptomyces lividans. Journal of General Microbiology 129, 27032714.

Kelemen, G. H., Cundliffe, E. \& Finansek, I. (1991). Cloning and characterization of gentamicin-resistance genes from Micromonospora purpurea and Micromonospora rosea. Gene 98, 53-60.

KIESER, T. (1984). Factors affecting the isolation of CCC DNA from Streptomyces lividans and Escherichia coli. Plasmid 12, 19-36.

Leskiw, B. K., Aharonowitz, Y., Mevarech, M., Wolfe, S., Vining, L. C., Westlake, D. W. S. \& Jensen, S. E. (1988). Cloning and nucleotide sequence determination of the isopenicillin $\mathrm{N}$ synthetase gen from Streptomyces clavuligerus. Gene 62, 187-196.

Malpartida, F. \& Hopwood, D. A. (1986). Physical and genetic characterization of the gene cluster for the antibiotic actinorhodin in Streptomyces coelicolor A3(2). Molecular and General Genetics 205, 66-73.

Malpartida, F., Hallam, S. E., Kieser, H., Motamedi, H., HatchInson, C. R., Butler, M. J., Sugden, D. A., Warren, M., McKillop, C., Bailey, C. R., Humphreys, G. O. \& Hopwood, D. A. (1987). Homology between Streptomyces genes coding for synthesis of different polyketides used to clone antibiotic synthesis genes. Nature, London 325, 818-821.

Maniatis, T., Fritsch, E. F. \& Sambrook, J. (1982). Molecular Cloning: a Laboratory Manual. Cold Spring Harbor, NY: Cold Spring Harbor Laboratory.
Matkovic, B., Piendl, W. \& Boeck, A. (1984). Ribosomal resistance as a wide spread self-defense mechanism in aminoglycosideproducing Micromonospora species. FEMS Microbiology Letters 24 273-276.

Murakami, T., Anzai, H., Imai, S., Satoh, A., Nagaoka, K. \& THOMPSON, C. J. (1986). The bialaphos biosynthetic genes of Streptomyces hygroscopicus: molecular cloning and characterization of gene cluster. Molecular and General Genetics 205, 42-50.

Nagano, E., Hasegawa, M. \& Kawamoto, I. (1988). Novel cloning vectors. Japanese Patent Kokai 63, 135031.

Nakano, M., Mashiko, H. \& Ogawara, H. (1984). Cloning of the kanamycin resistance gene from a kanamycin-producing Streptomyces species. Journal of Bacteriology 157, 79-83.

Nara, T. Yamamoto, M., Kawamoto, I., Takayama, L., OKachi, R., Takasawa, S., Sato, T. \& Sato, S. (1977). Fortimicins A and B, new aminoglycoside antibiotics. I. Producing organism, fermentation and biological properties of fortimicins. Journal of Antibiotics 30, 532-540.

Odakura, Y., Kase, H., Itoh, S., Satoh, S., Takasawa, T., Takahashi, K., Shirahata, K. \& Nakayama, K. (1984). Biosynthesis of astromicin and related antibiotics. II. Biosynthetic studies with blocked mutants of Micromonospora olivasterospora. Journal of Antibiotics 37, 1670-1680.

Ohba, K., Shomura, T., Tsuruoka, T., Kojima, M., Inoue, S. \& Itoh, T. (1981). Production of antibiotic SF-2098. Japanese Patent Kokai $56-18600$

OhNuKI, T., Imanaka, T. \& Aiba, S. (1985). Self-cloning of an str gene cluster for streptomycin biosynthesis and streptomycin resistance. Journal of Bacteriology 164, 85-94.

OHTA, T. \& HASEgaWa, M. (1989). Cloning and characterization of the self-defense gene of $S$. tenjimariensis and its distribution. In Trends in Actinomycetology in Japan, pp. 89-90. Edited by Y. Koyama and others. Tokyo: Society for Actinomycetes.

Ohta, T., Hashimoto, E. \& Hasegawa, M. (1992). Cloning and characterization of sms 13 encoding sannamycin glycyltransferase gene of Streptomyces sannanensis. Journal of Antibiotics 45, 11671175.

OKami, Y., HotTa, K., Yoshida, M., IKeda, D., Kondo, S. \& UmEZAWA, H. (1979). New aminoglycoside antibiotics, istamycins A and B. Journal of Antibiotics 32, 964-966.

PIENDL, W. \& BoECK, A. (1982). Ribosomal resistance in gentamicin producer organism Micromonospora purpurea. Antimicrobial Agents and Chemotherapy 22, 231-236.

Piendl, W., Boeck, A. \& Cundliffe, E. (1984). Involvement of $16 \mathrm{~S}$ ribosomal RNA in resistance of the aminoglycoside-producers Streptomyces tenjimariensis, Streptomyces tenebrarius and Micromonospora purpurea. Molecular and General Genetics 197, 24-29.

REED, K. C. \& MANN, D. A. (1985). Rapid transfer of DNA from agarose gels to nylon membranes. Nucleic Acids Research 13, $7207-7220$.

Rhodes, P. M., Hunter, I. S., Friend, E. J. \& Warren, M. (1984). Recombinant DNA methods for the oxytetracycline producer Streptomyces rimosus. Biochemical Society Transactions 12, 586-587.

Schiffman, D., Mevarech, M., Jensen, S. E., Cohen, G. \& AharoNOWITZ, Y. (1988). Cloning and comparative analysis of the gene coding for isopenicillin N synthetase in Streptomyces. Molecular and General Genetics 214, 562-569.

SkegGs, P. A,. Thompson, J. \& Cundliffe, E. (985). Methylation of 16 S ribosomal RNA and resistance to aminoglycoside antibiotics in clones of Streptomyces lividans carrying DNA from Streptomyces tenjimariensis. Molecular and General Genetics 200, 415-421.

SkegGs, P. A., Holmes, D. J. \& Cundliffe, E. (1987). Cloning of aminoglycoside-resistance determinants from Streptomyces tenebrarius and comparison with related genes from other actinomycetes. Journal of General Microbiology 133, 915-923.

Stackebrandt, E. \& Charfreitag, O. (1990). Partial 16S rRNA primary structure of five Actinomyces species: phylogenetic implications and development of an Actinomyces israelii-specific oligonucleotide probe. Journal of General Microbiology 136, 37-43.

Stanzak, R., Matsushima, P., Baltz, R. H. \& Rao, R. N. (1986). Cloning and expression in Streptomyces lividans of clustered 
erythromycin biosynthesis genes from Streptomyces erythreus. Bio/Technology 4, 229-232.

Watanabe, I., Deushi, T., Yamaguchi, T., Kamiya, K., Nakayama, M. \& MORI, T. (1979). The structural elucidation of aminoglycoside antibiotics, sannamycins A and B. Journal of Antibiotics 32, 1066-1068.

Weigel, B., Burgett, S. G., Chen, V., Skatrud, P. L., Frolik, A., QUEENER, S. W. \& INGOLIA, T. D. (1988). Cloning and expression of isopenicillin $\mathrm{N}$ synthetase genes from Streptomyces limpmanii and
Aspergillus nidulans: prokaryotic homologies of an antibiotic biosynthetic gene. Journal of Bacteriology 170, 3817-3826.

Yamamoto, H., Hotta, K., Okami, Y. \& Umezawa, H. (1981). Selfresistance of a Streptomyces which produces istamycins. Journal of Antibiotics 34, 824-829.

Yamamoto, H., Нотta, K., OKam, Y. \& Umezawa, H. (1986). Ribosomal resistance of an istamycin producer, Streptomyces tenjimariensis, to aminoglycoside antibiotics. Biochemical and Biophysical Research Communications 100, 1396-1401. 